\title{
Aleksandr Bogdanov's Concept of Culture: From Workers' Circles to the Proletkult Movement
}

\author{
JUTTA SCHERRER \\ Ecole de hautes études en sciences sociales, Paris, France; email: scherrer@ehess.fr \\ Commentary by DAVID ROWLEY
}

\begin{abstract}
Keywords: proletarian culture, art, science and philosophy; Proletkult organization; proletarian university, proletarian encyclopedia

This paper analyses the historical genesis of Aleksandr Bogdanov's conception of proletarian culture. In particular, the author deals with Bogdanov's activity during his exile in Vologda, his organization of the Vpered group, and the debates over cultural politics amongst Russian Marxism in emigration. The systematic focus of the paper is on the concept of culture as based on the material and non-material capacities of the comprehension and the working and living conditions of the worker. The role of art in a system of culture is another important systematic focus of this analysis.
\end{abstract}

In the middle of the 1890s when Aleksandr Bogdanov (Malinovskiy), still a student of medicine, was organizing workers' study circles in Tula, the notion of workers' culture was rarely debated by Russian revolutionaries and Marxists. The situation in Russia was very different from that in Germany where social-democracy constituted already a mass party with a highly structured network of organizations devoted to the educational and cultural tasks of the workers. Here, the term Arbeiterkultur was widespread and leading social-democrats considered the party not only as a carrier of the economic and political emancipation of the proletariat, but also as a broad working class cultural movement.' In general, their understanding of Arbeiterkultur was oriented towards bourgeois culture and did not differentiate substantially between culture and way of life. Literature conceived by workers themselves was mostly rejected, and this not because of its socialist tendencies, but because of its low aesthetic level. In Russia, where the founding members of the Russian Social-Democratic Workers' Party were immediately arrested after its illegal foundation (1898), the party had to struggle for its organizational survival.

In 1897 Bogdanov published the lectures that he had delivered at the workers'schools in Tula as A Short Course in Economic Science. This became the most popular textbook on Marxist political economy and it was reedited and enlarged ten times until the 1920s. In teaching workers the basics of Marxist political economy, Bogdanov had structured his course into questions and answers, a method which he employed also in later courses designed for a working class public. His first teaching experience

The large organisational network of cultural organisations was considered as « Arbeiterbewegungskultur », see the book by Gerhard A. Ritter with the same title. 
had made him aware of the particular effort of his worker-pupils to "connect technical and economic phenomena with the forms of spiritual culture arising out of them, like links in a single complex chain of development" (Bogdanov 1924: 240). ${ }^{2}$ It is exactly this observation of the specific spiritual needs of the Russian worker in comprehending the content, the presentation and the reflection of a given material as a totality, that constituted the starting point of what Bogdanov conceptualized more than a decade later as 'proletarian culture': a culture based on the material and non-material (spiritual) capacities and on the comprehension of the working and living conditions of the workers themselves. In other words: not a culture derived from the hegemonial bourgeoisie and adapted to the needs of the worker - an understanding implied by the German notion of Arbeiterkultur.

In what follows, I shall briefly show the most important steps in Bogdanov's general understanding of culture, which led to his particular conceptualization of proletarian culture. I shall not discuss here Bogdanov's political biography, his role in the consolidation of the Bolshevik organization and his rivalry with Lenin. There is, however, no doubt, that Lenin's, and even more so, Plekhanov's rigid conception of Marxism and, in particular, of historical materialism greatly influenced Bogdanov's conceptualization of an independent, hegemonial, proletarian culture.

During his periods of residence or exile in Tula, Kaluga and Vologda (1895-1904), Bogdanov discussed with his comrades Bazarov, Skvortsov-Stepanov and Lunacharskiy what they called the philosophical aspect of Marx's system. As Bogdanov wrote in his preface to the third volume of Empiriomonizm: since Marxism was not yet philosophically founded, they wanted to establish its philosophical foundation. In Lunacharskiy's words: they wanted to reinforce Marxism's gnoseological and ethical aspects independently of Plekhanov's reduction of Marxism to the materialism of the French encyclopaedists (Lunacharskiy 1919: 22). ${ }^{3}$ They denied from the outset that Marxism was a system of explanation of social reality, valid for all the time. Marxism, in their opinion, ought to evolve, progress, and be modernized with the most recent developments in science and philosophy by new, contemporary ideas. "The tradition of Marx and Engels must remain dear to us, not in the letter, but in its spirit" (Bogdanov 1908: 66). Bogdanov's proposition became the epistemological postulate of their group, which considered the empiriocriticism of Avenarius and Mach to be one of the most important openings of Marxism to modern science. It became the foundation of Bogdanov's system of empiriomonism.

In Vologda, which was the meeting place of a whole colony of political exiles (among them N.A. Berdyaev, B.V. Savinkov, A.M. Remizov, B.A. Kistyakovskiy, P.P. Rumyantsev), the group around Bogdanov clarified its conception of materialism ('realism') in theoretical confrontations with the 'idealists', among them, first of all, Berdyaev. The result was their collective volume Ocherki realisticheskogo mirovozzreniya [Essays on realistic philosophy] which appeared in 1904 as an answer to the collective volume Problemy idealizma [Problems of idealism] which contained major articles by the former so called Legal Marxists Berdyaev, Bulgakov, Frank and others and had appeared at the end of 1902 (Scherrer 1981: 113-152; Steila 1996:156-166). By a realistic worldview the group around Bogdanov understood the rejection of any metaphysical absolute and of any pretension of absolute truth (istina) in favor of the monistic ideal of cognition. In their collective volume they pleaded for the unity of theory and praxis, and the question of how one should understand 'superstructure' which later became fundamental for Bogdanov's conception of culture, was addressed.

In a collection of essays published in 1905 under the title Novyy mir (New World) Bogdanov developed his concept of collectivism. What he called sobiranie cheloveka (integration of man) implied the creative potential of each individual person in the collective. The education of the proletariat appeared already in this context as the highest goal. Twenty years later, in 1924, in the preface to a collection of his articles on proletarian culture Bogdanov referred to his early articles "as having already outlined 
the highest cultural type of life - the socialist type, which has its source in proletarian class culture" (Bogdanov 1924: 10). In other words, proletarian culture contains only elements of socialist culture: proletarian culture is socialist or collectivist culture in the process of evolution.

Bogdanov's analysis of the failure of the revolution 1905 and his confrontation with Lenin over Bolshevik strategy after 1905 made it evident for him (and his comrades in ideas), that for organizational purposes the workers needed their own intelligentsia, a rabochaya intelligentsiya (workers'intelligentsia), and for ideological reasons they needed to become aware of their own class-consciousness which not only included the workers' behaviour, thinking, and ideology, but also philosophy, science, and the arts. In articles and pamphlets written after 1907, Bogdanov advocated the development of the cultural hegemony of the proletariat prior to its seizure of power. In a pamphlet directed straight at Lenin Ne nado zatemnyat' ('Do not obscure matters') Bogdanov asserted that "Bolshevism is not simply a political phenomenon, it is as much socio-cultural" (Maksimov 1909: 5). This kind of reasoning had led Bogdanov, Gorkiy, Lunacharskiy and other left bolsheviks to the founding of two social-democratic party schools for Russian workers which took place in Capri (August-December 1909) and Bologna (November 1910-March 1911). In the Capri school, as Bogdanov remembered 1918 in his article "Proletarian University" the term proletarian culture was first openly formulated (Bogdanov 1924: 10). All the teaching, comprising courses on political economy, socialism, trade unionism, history, philosophy, literature and art sought to interpret the entire history of the activity and thought of humanity not only from the point of view of the working being - what the worker could conceive - but even more as a complete product of the experience of the working human being. The goal of the party schools for workers was the development and organization of the class-consciousness of the proletariat, which for Bogdanov was identical with the proletariat's creative potential, namely proletarian culture. Bogdanov's recently published correspondence with Maksim Gorkiy shows to what degree the writer as well as Lunacarskiy were involved in Bogdanov's the conceptualization of proletarian culture during their Capri period (Scherrer/Steila 2017).

One of the results of the Capri-school was the creation of the Vpered group, an independent socio-cultural political faction of the Russian Social Democratic Workers' Party, founded by the lecturers and the majority of the worker-pupils of the Capri school in defence of a 'pure,',authentic' and 'true' Bolshevism, in opposition to the authoritarian individualism of Lenin's style of leadership. In the platform of the Vpered group, essentially drafted by Bogdanov, the notion of proletarian culture appears for the first time as a political watchword.

Let me quote a longer passage from the platform of the Vpered group, which, significantly enough, was taken up by Bogdanov in 1918 when pleading for a proletarian university:

"The bourgeois world, with its developed culture which has left its imprint upon modern science, art, and philosophy, rears us imperceptibly in its fold, while the class struggle and our social ideal draws us in the opposite direction. We should not break entirely with this culture, which is of the fabric of history, for we can and should discover in it a powerful weapon in the struggle against this same old world. To receive it as it is would mean conserving in ourselves this past against which the struggle is waged. There is but one solution: to use the previous bourgeois culture to create, in order to combat bourgeois culture, and to diffuse among the masses, a new proletarian culture: to develop a proletarian science, reinforce authentically fraternal relations in the proletarian milieu, elaborate a proletarian philosophy, and direct art towards the aspirations of the proletariat and its experience. This is the only route to attaining a universal socialist education, which would avoid the innumerable contradictions of our life and work, and which would augment considerably our forces in the struggle, and approximate at the same time to our ideal of socialism, while elaborating more and more of its elements in the present" (Sovremennoe polozhenie 1909/1910: 16-17).

In opposition to what Bogdanov considered to be the theoretical conservatism of Lenin and Plekhanov (Bogdanov 1911: 29-30), the platform of Vpered group called for the attainment of the 
cultural hegemony of the proletariat alongside its political hegemony because politics formed an organic whole with the other aspects of ideological life of society. For Bogdanov, the socialist ideal included both political and cultural liberation. Socialism would be possible only when the proletariat developed its own intellectual and moral awareness, which could be counter-posed to the old cultural world (Bogdanov 1911; Sochor 1988: 185).

In an article written at the beginning of 1911 for the Vpered group, Sotsializm $v$ nastoyashchem (Socialism in the present day) Bogdanov developed his theory of comradely collaboration, or fraternal union at work (tovarishcheskoe sotrudnichestvo), which bound the proletariat together at work, stimulated its sense of psychological unity, of the organic consciousness of unity - in short, collectivism. What Bogdanov termed collectivism was the psychology of the working class, its consciousness of itself as a class. In fact, it was in the process of collective work that the fundamental type of organization of a whole class was constituted, which made the proletariat capable of elaborating new forms of life and thought, in brief, its culture. These fraternal and collectivist relations inside the working collective should become the organizational base of the party as much as of the proletarian family structure; they should serve for the elaboration of a new science, a new philosophy and a new art that of proletarian culture.

In 1911 Bogdanov left the Vpered group because of émigré infighting and politicking. Some of his former comrades did not find it realistic "to create as of now on in the midst of existing society a great proletarian culture, stronger and more structured than the decaying culture of the bourgeois classes and immeasurably more free and creative" (Maksimov 1909: 5). In fact, a group around Aleksinskiy wished to revert to traditional political-economic as opposed to cultural priorities. From this moment on Bogdanov concentrated on his theoretical work. The first result was the 92- page long treaty Kult'urnye zadachi nashego vremeni (Cultural tasks of our time), which appeared that same year. Drawing on his experiences in the party schools, Bogdanov elaborated here for the first time, systematically, the concept of proletarian culture which contained essentially all the aspects of proletarian culture that he had conceptualized until then and which he was to develop later (Bogdanov 1911).

Here, as in other writings, Bogdanov distinguished three successive types of culture, each of which depended on a type of organization of labour, that is, of a technological level of society in different states of development: authoritarian culture, individualist culture, and collectivist culture.

It was the collective experience acquired during the work process that had given rise not only to the first acquisition of technological and scientific knowledge, but also to myths, religious legends, songs, poetry and to the classics of literature. The experiences of active man in the process of labour were at the source of all these creations. Scholars and artists, as individuals, often of non-proletarian origin, do no more than transcend the experience of the working collective. They are, in fact, the conveyor belt of the collectivity. Each discovery in astronomy or physics, each literary creation like an Othello, Hamlet, Faust, or William Tell, thus leads back to an experience of collective work. The true creator of spiritual culture (dukhovnaya kul'tura) is not, therefore, the solitary individual with his arbitrary act (proizvol) but the working being in the collectivity of work. The author, the creator, or the genius is quite simply the point (tochka prilozheniya) where the creative forces of society are concentrated in order to produce new forces through its consciousness. The author thus may be the creator, subjectively speaking, but objectively it is society (Bogdanov 1911: 41).

Bogdanov demarcated three essential areas in which the proletariat should create for itself a cultural system free of fetishism and individualist bourgeois norms (which were totally alienated from the social praxis of man), morality, arts and science. As the foundation of new social norms, Bogdanov fixed on the proletarian moral principle of fraternal solidarity (tovarishcheskaya solidarnost), mentioned above. The new social norms would correspond to the technical norms of work; they would be stripped of their abstract character and would be reduced to the organizational principles of human relations. All would depend on the needs of the collectivity, and all would be done according to its interests. 
The norms of morality, law and custom, as developed by proletarian class life, would correspond only to their utility for the collectivity and to its social needs. It would be necessary to devise a new terminology, for words like 'law,' 'morality' or 'religion', which, as attributes of absolute authority no longer had any meaning. At the same time, expressions like 'proletarian morality' or 'proletarian right' were inadequate: new cultural forms necessitated new concepts. Truth was defined here by the experience of work and by the praxis of the collective.

In like manner, the new proletarian art had to integrate experiences of the collectivity of work. The proletariat lived its own life distinct from that of any other class; hence it needed its own art imbued with its own feelings, aspirations and ideals. Bogdanov here energetically refuted the objections of those who held that the difficult conditions of working class existence and the still more arduous circumstances of the social struggle could hinder its assuming responsibility for its own art, at least as long as it was not in power. On the contrary, art organizes social experience through living images, not only in the domain of knowledge, but even more in the domains of feelings and wants. Since it discharges in this way an organizational function in the life of the collectivity, and by the fact that it harmonizes the feelings and ideals of the masses, it becomes the most powerful motor of the development and finally of the victory of the collectivity. The cohesion of the class would become the greater by the fact of art embracing a field larger than that of economy and polity.

In Kul'turnye zadachi nashego vremeni Bogdanov was not explicit on the forms of the new proletarian art."I leave this to others who are more competent than I on such questions" (Bogdanov 1911: 77). But, from the point of view of content, he deemed it especially false and naive to think that proletarian art ought to describe the life of workers, their byt (forms and mode of everyday life) and their struggle. The universe of the experiences of class, which is the object of the art of the class, is not for that reason in the least limited; it embraces all the being and all the byt of society just as much as all of nature. The proletariat lives alongside other classes, whether foreign or hostile, to which it is bound by numerous threads, spiritual, economic, and social. Many of these elements had been, consciously or otherwise, assimilated by the proletariat. And even if it combats them, they are after all a heritage of the classes of which the proletariat is the issue: the petite bourgeoisie (meshchanstvo) and the peasantry. Now, the more it knows these classes, their psychology, organization, and interests, the less the danger of submitting to their cultural influences; and it will be that much easier for the proletariat to imbibe from their culture what is useful and progressive. From the fact of the organizational function of art, "putting into form and consolidating a definite social organization" (Bogdanov 1911: 51), proletarian art would be able to show to workers at work, in their social struggle, and in their daily life, much of what escapes from their consciousness in the first instance. Thus art is a constitutive element of the consciousness of self (samosoznanie) of the proletarian class.

Since art organizes the human experience of labour, not in abstract concepts but in concrete, live images (zhivye obrazy), it is more democratic than science, more accessible to the masses. Yet, Bogdanov saw in the "democratization of scientific knowledge" the most urgent cultural task of the proletariat of his time. According to him it was not a question of literacy or of the assimilation of the specialized knowledge of distinct disciplines or of its popularization through pamphlets and public lectures, in the manner typical of bourgeois culture, but of wide knowledge. It was a question of realizing the "sum" of knowledge, hitherto split up in partial domains, of returning from specialization to general experience, and, by that, to the general system of human labour. The workers needed a global and unifying scientific explanation, which would furnish them with a general awareness of the existing relation between the different technical methods, which they would apply with their own hands in production, and of the different methods, social, economic, and ideological, that were important for the organization of the class and for the fate of workers. The workers, therefore, should have access to the systematization of the different domains of scientific experience and to transcend specialist 
discourse. Hence the idea of creating a Proletarian University (of which the schools of Capri and Bologna were the precursors) that would embrace all the fundamental sectors of science in its teaching.

It was with the same concern to systematize all the scientific experience of his time and to make it accessible to the working class that Bogdanov returned to the project of a workers' encyclopaedia that had been launched during the Capri school. Just as the Great Encyclopaedia of the eighteenth century had co-ordinated the fragmented knowledge and experience of the era of the bourgeoisie, the new encyclopaedia would now explain the science and philosophy of labouring mankind as the means towards the organization of the collective activity of man.

The proletarian democratization of knowledge, that is, the creation of a proletarian science and of a proletarian philosophy was undertaken by Bogdanov in the following years in his Tektology or Universal science of organization (Vseobshchaya organizatsionnaya nauka), the first volume of which appeared in 1912, and in which he proposed to lay the foundation of a science which aimed to unify the entire organizational experience of all of humanity, and to synthesize all the knowledge accumulated by specialized disciplines.

In general it can be said that proletarian culture as conceived by Bogdanov before 1917 was not 'popular culture' or the culture of the popular masses. It was not defined by popular arts and traditions or by folklore. It had nothing to do with making the masses literate, educating them or simply appropriating or assimilating bourgeois culture any more than with rejecting the cultural heritage. It did not propose, either, a true aesthetics: one would search in vain for a precise aesthetic approach in Bogdanov's dilettantish analyses, in which the concrete content of proletarian culture remained rather abstract. For him it was above all matter of making the proletariat conscious of what was inherent in its "byt", to deliver its internal culture. This was an internal comprehension of themselves: their life, labour, feelings, emotions, ideals, attitudes, and mentality, in short, that they should acquire a consciousness of self (samosoznanie) by appealing tirelessly to the collective will, which was for Bogdanov the same as combative creativity. Only the elaboration of this independent culture could guarantee to the proletariat its entire independence and autonomy.

These conditions were not fulfilled in 1917. Bogdanov did not contest the achievements of the October revolution but he did question its socialist character, given the lack of cultural maturity of the proletariat as a whole. During 1917 he worked in the Cultural and Educational Department of the Moscow Soviet and between 1918 and 1921 he devoted himself to the Russian Proletarian Cultural Educational Association or Proletkul't which was founded in Petrograd in October 1917 and of whose Central Committee he was a member. Here he worked together with his former comrades from the vered group who had created in 1913 in Paris and Geneva under the direction of Lunacharskiy a Circle of Proletarian Culture with P. Bessalko, M. Gerasimov, A. Gastev, F. Kalinin, P. Kerzhentsev, P. Lebedev- Polyanskiy and a number of proletarian poets and writers who now played a major role in the Proletkult organization. Lunacharskiy, Commissar of Education, was at least in the beginning helpful in protecting the Proletkult's autonomy .

Bogdanov's commitment to the Proletkult organization, which I cannot describe here in detail, was based on his conviction that the key to socialism lay in the sphere of culture: unless socialism meant cultural liberation, it meant very little. In the pages of Proletarkkaya kul'tura, Proletkult's main journal to whose editorial board Bolgdanov belonged, he argued that the Proletkult organization should be open only to the most highly qualified workers of the leading industrial sectors as well as to the most mature and active workers. Only they could organize the cultural and ideological leadership, the hegemony of the political bloc over the petty bourgeois and peasant culture produced by the broad masses. Just as the party could not accept that its political line would be determined by the least conscious workers, Bogdanov argued, so also the Proletkult could not admit that its cultural line should be determined by the least conscious workers. The Proletkult should become, by analogy with the party, an organization for the cultural vanguard of the working class and also 
represent in Bogdanov's terms, a sort of "laboratory of the pure proletarian ideology" (Bogdanov 1919: 26-29). Bogdanov's particular understanding of culture brought him again into opposition to Lenin who argued, as is generally known, that in the particular conditions of Russia's backwardness a true bourgeois culture should suffice as the basis of a workers' education.

As before 1917, Bogdanov was less interested in concrete, applied aesthetics and forms of proletarian art, but much more in theoretical and organizational questions of the Proletkult. As before, proletarian culture meant for him, in the first instance, the independent creativity of the proletariat to acquire its own consciousness. For the socialization of science, the core issue of proletarian culture, a Proletarian University, a proletarian encyclopaedia and a proletarian library for scientific-philosophical works were founded, inspired by the experiences acquired in the Capri and Bologna party schools. Among Bogdanov's numerous writings on behalf of the Proletkult, none was written in support of the maximalist tendency of some of the Proletkult representatives such as V. T. Kirillov who wished to abandon the entire cultural heritage of former generations - a reproach made of Bogdanov by Lenin and subsequent Soviet historiography until its very end, with the intention to discredit him.

It was certainly the merit of Proletkult and of Bogdanov to have posed the question of culture as central for the revolution. But Bogdanov and the Proletkult were unable to mobilize for their goal the proletarian vanguard and to develop an independent Proletkult aesthetics.

In general, it can be said that Bogdanov, "like the early anthropologists understood culture in the broadest sense, as encompassing tools, means of cooperation, speech, knowledge, art, customs, laws, ethics and so on - in other words, all the products, material and nonmaterial, of human labour" (Sochor 1988: 68). Mostly, however, he referred to culture in the narrower sense, what he called 'spiritual culture', which included worldviews, artistic creativity, aesthetics, and political relations. He used culture in this sense synonymously with ideology or science of ideas which he defined as the social consciousness of people (Bogdanov 1911: 3; Sochor 1988: 68). Bogdanov's principal idea was that culture in its many forms, whether speech, knowledge, customs, or art had an internal structure, an implicit organizational function. Culture plays a real, practical role in society, an organizational role. Rather than treat culture as an epiphenomenon, as implied in Marx's use of the term superstructure, Bogdanov defined culture as a type of infrastructure in society with its own specific role (Sochor 1988: 70).

There is no doubt that independently from his more praxis oriented conceptualization of proletarian culture Bogdanov developed also a more anthropological understanding of culture in works such as Filosofiya zhivogo opyta, Nauka ob obshchestvennom soznanii and Tektologiya. But this would be another topic of reflection.

\section{Commentary by David Rowley}

What particularly strikes me in Jutta Scherrer's article is the evidence she provides for appreciating the unity of theory and practice in Bogdanov's work. The fundamental question for a historical materialist is how being determines consciousness, and Bogdanov answered it by asserting that the technology of production is primary, and that cognitive and normative ideological forms (including art) are secondary (Bogdanov 2020: 332). He further asserted that the fundamental class division in society is between organizers (those who master the technology of the era and who are in charge of production) and implementers (those who carry out the directives of the organisers). Bogdanov explains the specialization of bourgeois science, the dualism of bourgeois philosophy, and the absolutism of bourgeois morality as consequences of the role the bourgeoisie played in organizing capitalist production. 
The transition to socialism, according to Bogdanov, will be the consequence of a change in the technology of production - that is, the transition to production by self-regulating automatic machines. By overseeing such machines, workers will become organizers as well as implementers, and 'the unity of cognitive methods (the highest form of monism) that is developing will make human thinking an increasingly systematic and harmonious system' (Bogdanov 2022: 137). This new type of thinking will lead to collectivism - or the 'integration of man' - as Scherrer points out.

Bogdanov's unity of theory and practice encompasses the idea that it is because of their relation to the technology of production that proletarians must be the leaders in the creation of proletarian (socialist, collectivist) culture. As Scherrer shows, at every stage of Bogdanov's development of the idea of proletarian culture, workers are the prime movers: during his exile in Tula, Bogdanov's worker-pupils led him to 'connect technical and economic phenomena with the forms of spiritual culture arising out of them'; the Party Schools at Capri and Bologna were intended to foster the self-development of proletarians; and finally, 'the Proletkult organization would be open only to the most highly qualified workers of the leading industrial sectors'.

Bogdanov had anticipated this idea in The Cultural Tasks of Our Time, when he presented the idea of the Proletarian University (and the Proletarian Encyclopaedia, which will arise from it and which will embody the ultimate expression of the proletarian world view). The new university will not be open to children fresh from (bourgeois) high school and with no experience in productive labour. Instead, students of the "New University" will "already be essentially adults with serious experience in the sphere of labour and social struggle .... Such 'students' will be real comrades of their 'professors' and in their turn will lead the professors in fulfilling their collective-creative task" (Bogdanov 1911: 70).

Bogdanov's confidence in the ability of proletarians to create proletarian culture was the logical consequence of his belief that being determines consciousness.

\section{References}

Bogdanov, AA. 1908. Priklyuchenie odnoj filosofskoj shkoly. St. Petersburg.

Bogdanov, AA. 1911. Kul'turnye zadachi nashego vremeni. Moskva: S. Dorovatovskiy and A. Charushnikov.

Bogdanov, AA. 1919. "Plan organizatsii Proletkul'ta". Proletarkaya kul'tura. No. 6 (February). - 1924. O proletarskoy kul'ture. Moskva-Leningrad: Kniga.

Bogdanov, AA. 2020. Empiriomonism: Essays in Philosophy, Books 1-3. Leiden; Boston: Brill.

Bogdanov, AA. 2022. Toward a New World: Articles and Essays, 1901-1906. Leiden; Boston: Brill.

Gloveli, G. 1998. Bogdanov as Scientist and Utopian. Bogdanov and His Work. A guide to the published and unpublished works of Alexander A. Bogdanov (Malinovsky) 1873-1928, edited by John Biggart, Georgii Gloveli, Avraham Yassour. Ashgate: Aldershot 1998.

Lunacharskiy, AV. 1919. Moe partiynoe proshloe. Lunacharskiy, A. V. Velikiy perevorot (Oktyabrskaya revolyutsiya). Part 1. Peterburg: Izd. Z.I. Grzhebina.

Maksimov, N. 1909. Ne nado zatemnyat. Ko vsem tovarishcham! Paris: RSDRP (before 28 November / 11 December).

Ritter, GA. 1979. Arbeiterkultur. Taunus: Königstein.

Scherrer, J. 1981. L'intelligentsia russe: sa quête de la 'vérité religieuse du socialisme. Le temps de la réflexion II. Paris: Gallimard.

Scherrer, J. 1989. The Cultural Hegemony of the Proletariat: The Origins of Bogdanov's Vision of Proletarian Culture. Studies in History, 5,2. 
Scherrer, J. and Steila, D. 2017. Gor'kij-Bogdanov e la scuola di Capri. Una corrispondenza inedita (1908-1911). Roma: Carocci editore.

Sochor, ZA. 1988. Revolution and Culture. The Bogdanov-Lenin controversy. Ithaca and London: Cornell Press University.

Steila, D. 1996. Scienza e rivoluzione: La recezione dell'empiriocriticismo nella cultura russa (1877-1910). Firence: Le Lettere.

\section{Authors information}

Jutta Scherrer is Director of research at the Ecole des hautes études en sciences sociales, Paris since 1980. She is teaching Russian history and is particularly engaged with analysis of socio-cultural, philosophical and political phenomena of the 19th and 20th centuries. She has published extensively on Russian intelligentsia, Russian Marxism, Russian orthodoxy and religious philosophy. Her more recent research deals with identity construction in post-Soviet Russia, historical memory and « politics of history ». She was during many years member of the scientific council of the Institute for the Study of Eastern Europe in Leipzig (GWZO), of the German Historical Museum in Berlin and the German-Russian Museum in Berlin-Karlshorst.

David G. Rowley (PhD, University of Michigan) is Emeritus Professor of History, University of Wisconsin-Platteville. He has published several articles on Alexander Bogdanov, and he is co-editor with Evgeni Pavlov of the Brill/Historical Materialism "Bogdanov Library". Three of his translations for the Library have been published so far: The Philosophy of Living Experience (2016), Empiriomonism (2020), and Toward a New World: Articles and Essays, 1901-1906 (2022).

\section{○ \\ OPEN ACCESS}

Copyright: @ 2021 The Author(s). This is an open-access article distributed under the terms of the CreativeCommons Attribution 4.0 International License (CC-BY 4.0), which permits unrestricted use, distribution, andreproduction in any medium, provided the origina author and source are credited. See http://creativecommons.org/licenses/by/4.0/. 